\title{
Residential Radon in Central and South America: A Systematic Review
}

\author{
Alexandra Giraldo-Osorio ${ }^{1,2}$, Alberto Ruano-Ravina ${ }^{1,3, *} \mathbb{C}$, Leonor Varela-Lema ${ }^{4}(\mathbb{D}$, \\ Juan M. Barros-Dios ${ }^{1}$ (D) and Mónica Pérez-Ríos ${ }^{1,3}$ \\ 1 Department of Preventive Medicine and Public Health, University of Santiago de Compostela, \\ 15782 Santiago de Compostela, Spain; alexandra.giraldo.osorio@usc.es (A.G.-O.); \\ juanm.barros@usc.es (J.M.B.-D.); monica.perez.rios@usc.es (M.P.-R.) \\ 2 Grupo de Investigación en Promoción de la Salud y Prevención de Enfermedades, Departamento de Salud \\ Pública, Universidad de Caldas, Manizales 170002, Colombia \\ 3 Consortium for Biomedical Research in Epidemiology \& Public Health (CIBER en Epidemiología and Salud \\ Pública/CIBERESP), 15782 Santiago de Compostela, Spain \\ 4 Galician Health Technology Assessment Agency, Health Knowledge Management Agency (Axencia de \\ Coñecemento en Saúde/ACIS), Galician Regional Health Authority, 15706 Santiago de Compostela, Spain; \\ avalia-t1@sergas.es \\ * Correspondence: alberto.ruano@usc.es
}

Received: 15 May 2020; Accepted: 20 June 2020; Published: 24 June 2020

\begin{abstract}
Radon gas is a pulmonary carcinogen and the second leading cause of lung cancer after smoking. There are many countries that have not implemented measures to reduce the risk it poses to the general population. The aim of this study was to locate available evidence on exposure to residential radon and the regulations to monitor and control this across Central and South America, by conducting a review of the scientific literature and government documents in accordance with the Preferred Reporting Items for Systematic Reviews and Meta-Analyses (PRISMA) guidelines. This review included 31 studies which had taken measurements of radon in these countries. While Brazil, Argentina, and Peru have undertaken most research, no country in Central and South America has a national map of exposure to residential radon. The prevalence of exposure to radon was uneven, both among the different countries and within individual countries. No country has regulations to prevent the entry of radon into homes, and nine countries have not set maximum permissible concentrations for residential radon. There is a limited number of studies in South and Central America, with a limited spatial coverage, and there is a need to improve knowledge on exposure to residential radon and its effects, and for governments to take the necessary actions to introduce preventive measures in their statutory regulations.
\end{abstract}

Keywords: radon; lung neoplasms; lung cancer risk in never-smokers; residential radon; natural radiation

\section{Introduction}

Radon is a gas that originates from the disintegration of uranium contained in rocks forming part of the Earth's crust. It is colorless, odorless, and tasteless, and in the process of decay emits an alpha form of ionizing radiation. Radon has a number of isotopes, the most relevant of which from an epidemiologic standpoint is ${ }^{222} \mathrm{Rn}$, whose parent element in the radioactive decay chain is uranium 238. ${ }^{222} \mathrm{Rn}$ has a mean life of 3.8 days and is transformed into short half-life daughters that also emit alpha radiation, i.e., 218polonium and 214polonium [1]. Homes constructed in places where the rocks in the Earth's crust contain high uranium concentrations have a greater likelihood of experiencing high indoor radon concentrations, if they are not well insulated from the subsoil [2]. Indoor radon can be measured using different devices and technologies, and the most used and reliable to determine 
residential radon concentration is based on counting alpha particles impacting on a surface (alpha-track devices or Solid State Nuclear Track Devices) [3]. These detectors have to be placed for a minimum period of 3 months.

Numerous studies have associated occupational and residential exposure to radon gas with a higher risk of developing lung cancer, with 6 to $18 \%$ of all cases being attributed to this cause [4-8]. As a risk factor for lung cancer, radon is ranked second after smoking and first among never-smokers $[2,7,9]$, and is recognized by the International Agency for Research on Cancer (IARC) as a carcinogenic agent in humans [10]. Radon maps have been plotted in Europe and North America, which not only make it possible to identify geographic areas with higher radon concentrations, but also serve to define risk areas [11] and establish different levels of prevention measures. In many countries, such prevention measures are contained in legislation that addresses this public health problem [12].

In Central and South America, lung cancer is one of the most frequent cancers and the leading cause of cancer-related death in both sexes [13,14]. Across the period 1985-2008, lung cancer mortality was the leading or second leading cause of death among men in half of the countries in Central America and $80 \%$ of the countries in South America [13]. In women, the pattern was different: the countries reporting the highest lung cancer mortality rates were Venezuela, Argentina, Colombia, and Brazil [13].

Given the epidemiologic relevance of lung cancer in Central and South America, and the important role played by interior radon in the disease's appearance, it is crucial to ascertain what information there is on exposure to residential radon and what regulations have been established to govern radon in these countries. This information will make it possible to strengthen or initiate prevention activities aimed at reducing exposure to this carcinogen in a geographic area inhabited by more than 400 million people.

The main objective of the present study is to review the scientific evidence available on studies performed in Central and South America describing residential radon exposure, and also to describe regulations and by-laws enacted on preventive measures and maximum allowable indoor radon concentrations in such countries.

\section{Materials and Methods}

To carry out this study, we undertook a systematic review of the literature in accordance with the Preferred Reporting Items for Systematic Reviews and Meta-Analyses (PRISMA) guidelines [15].

\subsection{Search Strategy}

A bibliographic search was conducted in the PubMed (MedLine), Embase, Latin American \& Caribbean Health Sciences Literature (LILACS), and Biblioteca Virtual en Salud (BVS) databases and via the Google Scholar search engine, using search strategies that combined MeSH terms and free-text terms as follows: (("radon"[MeSH Terms] OR "radon"[All Fields]) AND ("South America"[All Fields] OR "south america"[MeSH Terms])), (("radon"[MeSH Terms] OR "radon"[All Fields]) AND ("Central America"[All Fields] OR "central america"[MeSH Terms])). In addition, further combinations were made with the names of the respective countries of Central America (Guatemala, Honduras, El Salvador, Nicaragua, Costa Rica, Panamá OR Panama) and South America (Colombia, Venezuela, Brasil OR Brazil, Perú OR Peru, Ecuador, Bolivia, Uruguay, Paraguay, Chile, Argentina). A thorough search was also made of government ministry websites hosted by the respective study countries, seeking all relevant documents, protocols, and administrative documents. Where necessary, we contacted the authors of scientific papers and reports to ascertain the existence of additional unpublished research. No time limit was set, and all publications available in the databases until February 2020 were included. We considered papers in international peer-reviewed papers and other types of papers, such as conference papers, papers in national journals, or documentation uploaded in institutional websites. The citations contained in the papers published were reviewed, and no language limits were imposed. Special emphasis was laid on the comprehensiveness of the search, so as to be sure to include all relevant information, albeit at the risk of obtaining irrelevant data that would subsequently have to be discarded. 


\subsection{Study Selection and Eligibility Criteria}

The initial selection of papers was made on the basis of the information contained in the title or abstract shown on the register. To qualify for inclusion, studies were required to report a minimum of 10 measurements of residential radon in a rural or urban setting in one or more Central and South American countries or some geographic area of these. Studies that included more than 3 provinces or districts were treated as nation-wide studies. There were no restrictions in terms of type of study or publication. In the case of any paper that successfully passed the first filter, its full text was requested for the purpose of verifying its compliance with the eligibility criteria.

When it came to statutory rules and regulations, only government documents were considered, with the exclusion of all publications by scientific societies, groups of experts, regions, counties, or any other entity at a subnational level. Similarly, regulations governing occupational exposure to radon were not included, since this aspect fell outside the scope of our review. We also excluded, because it was outside the scope of this research, radon presence in kindergartens, schools, public places, hospitals, or other non-residential settings.

\subsection{Data-Extraction, Management and Data Synthesis}

The same information was extracted from all the papers included, using a data-extraction table for the purpose. Data were obtained on the following variables: country; method of measurement; geographic area (province, municipality, district); number of provinces, municipalities, or districts; setting (urban, rural); number of homes measured; and radon concentration in becquerels per cubic meter $\left(\mathrm{Bq} / \mathrm{m}^{3}\right)$ (maximum, minimum and average, geometric mean or median). Information was extracted from each reference by two team members, with any disagreements or discrepancies in interpretation of the data being settled by consensus. A qualitative data synthesis was performed.

\section{Results}

\subsection{Summary of Studies Included}

Figure 1 shows the flowchart of the published papers describing indoor radon concentration retrieved. A total of 31 studies fulfilled the inclusion criteria. Most of the documents located were papers on scientific reviews. The first study to target residential radon dated from 1982 and was carried out in Rio de Janeiro, Brazil [16]. The greater part of the records corresponded to measurements of residential radon exposure made in Brazil, with 15 studies, and in Argentina and Peru, with six studies in each.

\subsection{Information Available on Residential Exposure to Radon}

Table 1 gives a description of the studies selected, broken down by year of publication. In the Central American region, residential radon measurements were solely found for Costa Rica [17], while in South America they were found for Argentina [18-23], Brazil [16,21,23-35], Chile [20,36], Colombia [37], Ecuador [21,23,38,39], Paraguay [20], Peru [21,23,40-43], and Venezuela [21,44]. Most of the studies involved radon measurements taken in areas or regions within a given country. There was wide variation in the type of area (district, municipality, province, etc.) and setting (urban, rural, or both) where measurements were made and in the number of measurements taken. The number of homes measured by the studies identified, ranged from 13 through 2689. The highest number of measurements corresponded to Argentina: until 1998, 1630 measurements had been taken, with this figure rising to 2689 by 2006 [19,21-23]. Only three studies measured radon in more than 300 homes [16,21,22]. 


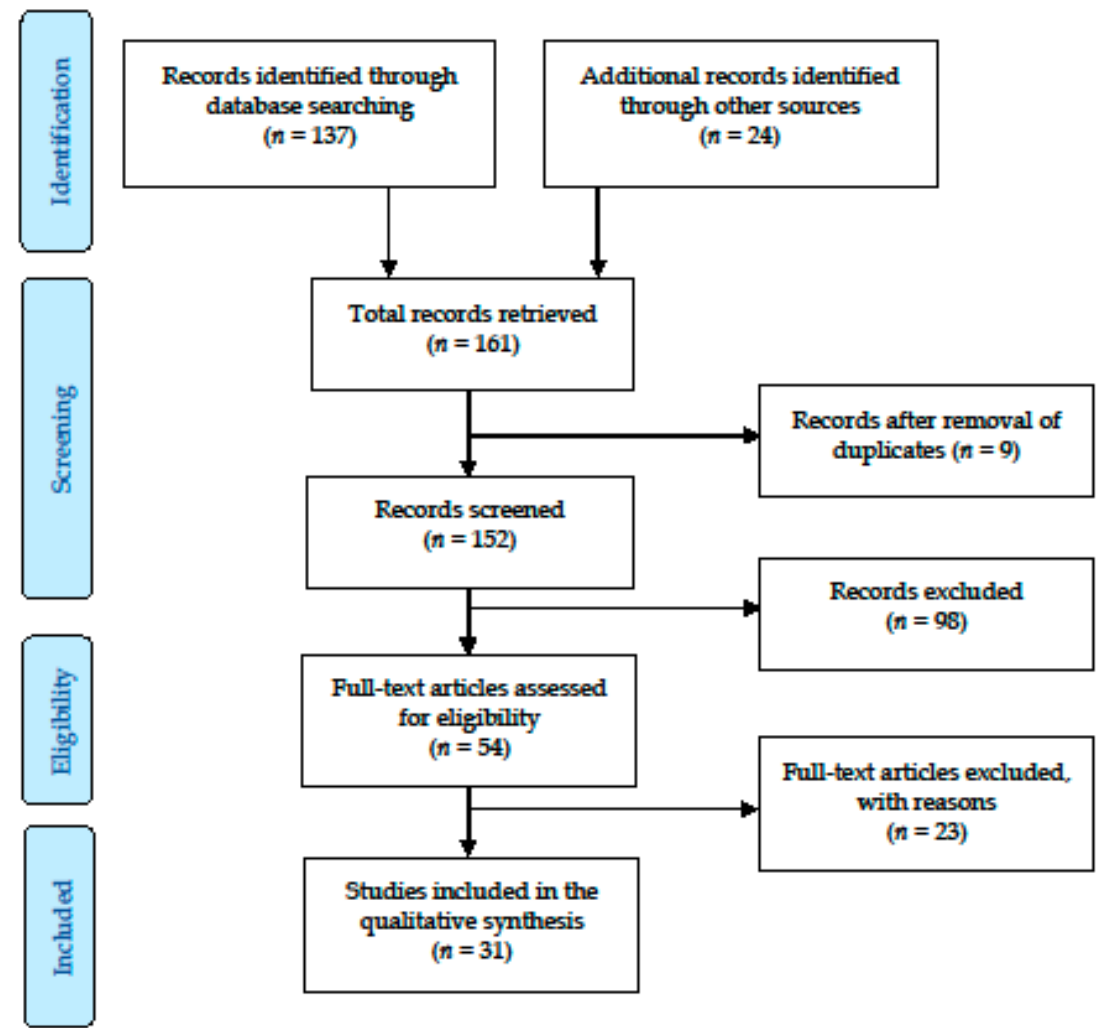

Figure 1. Flowchart of the included studies describing indoor radon concentrations.

The majority of measurements were made using the alpha-track technique, and essentially corresponded to studies of urban settings. Residential radon levels ranged from $0 \mathrm{~Bq} / \mathrm{m}^{3}$ through $3723 \mathrm{~Bq} / \mathrm{m}^{3}$. The highest levels were found in Brazil, and specifically in the following areas: Lages Pintadas, $3723 \mathrm{~Bq} / \mathrm{m}^{3}$ [32] and $2893 \mathrm{~Bq} / \mathrm{m}^{3}$ [33]; Belo Horizonte $2671 \mathrm{~Bq} / \mathrm{m}^{3}$ [31]; and Poços de Caldas, $1024 \mathrm{~Bq} / \mathrm{m}^{3}$ [26]. Brazil was also the country in which individual studies generally observed higher radon concentrations.

Radon concentrations found for each of the countries were highly variable, with Costa Rica showing the lowest concentrations and Brazil the highest. Nevertheless, since some of the included studies were performed in radon-prone areas, these results are not valid to produce a national average.

\subsection{Government Directives or Plans Governing Residential Radon Exposure and its Regulation}

Table 2 shows information on the regulations in force in each country. Three South American countries stipulated maximum reference levels in their legislation (Bolivia, Colombia, and Peru). In two Central American countries (Guatemala and Nicaragua) and two South American countries (Paraguay and Uruguay), residential radon action levels were in line with international guidelines: in the case of Guatemala, Nicaragua, and Paraguay, these were in accordance with the International Atomic Energy Agency (IAEA) Safety Series No. 115; and in the case of Uruguay, these were in accordance with the International Commission on Radiological Protection (ICRP) 1993 report No 65. In another nine countries, there was no mention of such radon reference levels for homes.

Differences were also observed between the action levels of countries that had established statutory levels. Hence, Bolivia and Colombia had a limit of up to $400 \mathrm{~Bq} / \mathrm{m}^{3}$, which was the most restrictive level of all countries across Central and South America, whereas Guatemala, Nicaragua, Paraguay, Peru, and Uruguay had the highest action level, i.e., up to $600 \mathrm{~Bq} / \mathrm{m}^{3}$. All of the Central and South America countries had statutory regulations governing ionizing radiations, but without specific allusion to the maximum level of exposure permitted. No legal rules or regulations were detected covering the prevention of accumulation of residential radon in any of the countries analyzed. 
Table 1. Description of radon measurement studies in Central and South American countries.

\begin{tabular}{|c|c|c|c|c|c|c|c|c|c|c|c|c|}
\hline \multirow{2}{*}{ Authors (Publication) } & \multirow{2}{*}{ Measurement Year } & \multirow{2}{*}{ Method of Detection } & \multirow{2}{*}{ Location * } & \multirow{2}{*}{ Coverage } & \multirow{2}{*}{$\begin{array}{c}\text { No. of } \\
\text { Areas ** }\end{array}$} & \multirow{2}{*}{ Setting } & \multirow{2}{*}{ No. of Homes } & \multicolumn{5}{|c|}{ Radon Level $\left(\mathrm{Bq} / \mathrm{m}^{3}\right)$} \\
\hline & & & & & & & & Max & Min & AM & GM & MED \\
\hline Urban M, et al. (1985) [16] & 1982 & Alpha-track & Brazil & Nationwide & 4 & Urban & 320 & 67 & 24 & 114 & - & - \\
\hline Gomez J C, et al. $(1990)[18,20]$ & $\begin{array}{l}\text { 1983-1985, } \\
1987-1988\end{array}$ & Alpha-track & Argentina, Buenos Aires & Autonomous city & 1 & Urban & 102 & - & - & 23 & - & - \\
\hline Gomez J C, et al. $(1990)[18,20]$ & $\begin{array}{l}1987-1988 \\
1983-1985\end{array}$ & Alpha-track & Argentina, San Rafael & Province & 1 & Urban and rural & 53 & - & - & 50.5 & - & - \\
\hline Gomez J C, et al. $(1990)[18,20]$ & 1984-1985 & Alpha-track & Argentina, Malargüe & Province & 1 & Urban and rural & 24 & & & 34 & - & - \\
\hline Loría LG, et al. (1993) [17] & & Alpha-track & Costa Rica & Nationwide & 25 & Urban & 45 & 30.3 & 8.1 & 13.85 & - & - \\
\hline Stuardo E $(1996)[20,36]$ & 1992-1993 & Alpha-track, electrets & Chile, Santiago & Municipality & 1 & Urban & 119 & 86 & 4 & 24.5 & - & - \\
\hline Malanca A, et al. (1997) [34] & $1995-1996$ & Alpha-track & Brazil, Natal & Municipality & 1 & Urban & 24 & 40 & 3.2 & 15.4 & 11.7 & - \\
\hline Malanca A, et al. (1997) [35] & 1995-1996 & Alpha-track & $\begin{array}{l}\text { Brazil, Rio Grande del Norte } \\
\text { and Ceará }\end{array}$ & State & 2 & Urban & 88 & 140 & 3.2 & 11.9 & 12.4 & 11.9 \\
\hline De Paula Melo, V (1999) [24] & 1997-1998 & Alpha-track & Brazil, Monte Alegre & Municipality & 1 & Urban & 33 & 188 & 27 & 75 & - & - \\
\hline De Paula Melo, V (1999) [24] & 1997-1998 & Alpha-track & Brazil, Inglés de Souza & Village & 1 & Rural & 35 & 200 & 32 & 116 & - & - \\
\hline Sajó-Bohus L, et al. (1999) [21,44-46] & 1993 & $\begin{array}{l}\text { Alpha-track, gamma } \\
\text { radiation }\end{array}$ & Venezuela & Nationwide & 1 & Urban & 36 & 41 & 31 & 36 & - & - \\
\hline $\begin{array}{l}\text { Guedes S, et al. (1999) [25] } \\
\text { UNSCEAR (2000) [20] }\end{array}$ & 1999 & $\begin{array}{l}\text { radiation } \\
\text { Alpha-track }\end{array}$ & $\begin{array}{l}\text { Brazil, Campinas } \\
\text { Paraguay }\end{array}$ & Municipality & 1 & Urban & $\begin{array}{l}15 \\
51\end{array}$ & 150.9 & 6.2 & $\begin{array}{c}43.98 \\
28\end{array}$ & - & - \\
\hline Canoba A, et al. (2001) [21,45] & 2000 & Alpha-track & Brazil, Campinas and & Municipality & 2 & - & 320 & 275.73 & 16.68 & 81.27 & - & - \\
\hline Canoba A, et al. (2001) [21,45,46] & 2000 & Electrets & $\begin{array}{l}\text { Presidente Prudente } \\
\text { Ecuador, Quito }\end{array}$ & Municipality & 1 & - & 61 & 187.78 & 35.9 & 94.3 & . & . \\
\hline Canoba A, et al. (2001) [21,45,46] & 2000 & Alpha-track & Peru, Lima & Municipality & 1 & & 168 & 46.43 & 22.14 & 64.59 & $=$ & - \\
\hline $\begin{array}{l}\text { Salazar S (2002) [37] } \\
\text { S }\end{array}$ & 2002 & $\begin{array}{l}\text { Aprdatrack } \\
\text { Electrets }\end{array}$ & Colombia, Manizales & Municipality & 1 & Urban and rural & 18 & $\begin{array}{l}40.40 \\
11.1\end{array}$ & 166.5 & $\begin{array}{l}0.59 \\
67.71\end{array}$ & $=$ & $=$ \\
\hline Magalhães M, et al. (2003) [27] & 1996-1997 & Alpha-track & Brazil, Rio de Janeiro & Municipality & 1 & Urban & 48 & 200 & $\begin{array}{c}10.3 \\
5\end{array}$ & & 40 & $=$ \\
\hline Magalhães M, et al. (2003) [27] & $1996-1997$ & Alpha-track & Brazil, Poços de Caldas & Municipality & 1 & Urban and rural & $\begin{array}{l}40 \\
125\end{array}$ & 985 & 31 & - & 132.5 & - \\
\hline $\begin{array}{l}\text { Veiga LH, et al. (2003) [26] } \\
\text { Vig }\end{array}$ & 2000 & Alpha-track & Brazil, Poços de Caldas & Municipality & 1 & Urban and rural & 138 & 1024 & 12 & 96 & 140.5 & - \\
\hline Paulo SR, et al. (2005) [28] & 2002 & Alpha-track & Brazil, Poços de Caldas & Municipality & 1 & Urban & 39 & 193 & 2 & 133 & 117 & - \\
\hline Canoba AC, et al. (2006) [19,21-23,45,46] & $1983-2006$ & $\begin{array}{l}\text { Alpha-track, activated } \\
\text { carbon, electrets }\end{array}$ & Argentina & Nationwide & 14 & - & 2689 & 300 & - & 41.6 & - & - \\
\hline De Olveira Santos T, et al. (2007) [29] & - & Continuous monitoring, & Brazil, Belo Horizonte & Municipality & 1 & Urban & 13 & 306 & 12.5 & 77.49 & - & - \\
\hline Zeeb H (2007) [23] & 2005 & $\begin{array}{l}\text { electrets } \\
\text { Alpha-track, electrets }\end{array}$ & Ecuador & Nationwide & 1 & - & - & 400 & 100 & - & . & - \\
\hline Zeeb H (2007) [23] & 2005 & Alpha-track & Peru & Nationwide & 1 & - & - & 600 & 200 & - & - & - \\
\hline Hadler J, et al. (2008) [30] & 1996-1997 & Alpha-track & Brazil, Campinas & Municipality & 1 & Urban & 70 & 286 & 11.8 & 80.6 & - & - \\
\hline Santos TO, et al. (2009) [31] & - & $\begin{array}{c}\text { Continuous monitoring, } \\
\text { electrets }\end{array}$ & Brazil, Belo Horizonte & Municipality & 1 & Urban & 13 & 2671.4 & 18.5 & 148 & 128.2 & - \\
\hline Thomas Campos, et al. (2011) [32] & - & Electrets, gamma & Brazil, Lages Pintadas & Municipality & 1 & Urban and rural & 100 & 3723 & 20 & 376 & 358 & - \\
\hline Campos TFC, et al. (2013) [33] & - & $\begin{array}{l}\text { Tradianion } \\
\text { Electrets }\end{array}$ & Brazil, Lages Pintadas & Municipality & 1 & Urban rural & 210 & 2893 & 15 & 566 & 291 & 288 \\
\hline Pereyra P et al. (2015) [40,41] & 2014 & Alpha-track & Peru, Lima & Province & 1 & Urban & 97 & 598.25 & 9.5 & 183 & - & - \\
\hline Cuadrado C, Carrasco J (2016) [39] & 2016 & Electronic detector & Ecuador, Riobamba & Municipality & 1 & Urban & 14 & 95 & 2 & 32 & - & . \\
\hline Liza Neciosup RA (2017) [42] & 2015-2016 & Alpha-track & Peru - Lima, San Martín de & District & 1 & Urban & 125 & 218.9 & 103 & 155.6 & 154.1 & 155.1 \\
\hline Vega Cabrera BO (2017) [43] & 2015-2017 & Alpha-track & $\begin{array}{c}\text { Porres } \\
\text { Peru-Lima, San Luis }\end{array}$ & District & 1 & Urban & 84 & 124 & 44 & 68 & 56 & - \\
\hline Loayza Cabrera MJ (2018) [38] & $2017-2018$ & $\begin{array}{l}\text { Alpha-track } \\
\text { Aldack }\end{array}$ & Ecuador, Cuenca & Municipality & 1 & Urban & 47 & 201.11 & 1.11 & 35 & - & 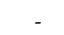 \\
\hline
\end{tabular}

${ }^{*}$ Location: indicates the country of South America (Peru, Ecuador, Venezuela, Brazil, Argentina, Chile, Paraguay, Colombia) or Central America (Costa Rica). ${ }^{* *}$ Areas: Political administrative division or jurisdiction in which the measurements were made (i.e., district, municipality, province, etc.). AM: arithmetic mean; GM: geometric mean; MED: median; -: no data. UNSCEAR United Nations Scientific Committee on the Effects of Atomic Radiation 
Table 2. Governmental regulations, ordinances, or plans governing residential radon exposure and home construction.

\begin{tabular}{|c|c|c|c|c|c|}
\hline Country & Regulation & $\begin{array}{c}\text { Year of } \\
\text { Publication }\end{array}$ & Body that Lays down the Regulation & $\begin{array}{l}\text { Action Level for Chronic Exposure to Radon } \\
\text { in Homes }\end{array}$ & $\begin{array}{l}\text { Building Regulations for Control of Radon } \\
\text { Levels }\end{array}$ \\
\hline Bolivia (South America) & $\begin{array}{l}\text { Supreme Decree 19172: Radiological } \\
\text { Protection and Safety Act }\end{array}$ & 1982 & $\begin{array}{l}\text { Bolivian Institute of Science and Nuclear } \\
\text { Technology: the national authority with } \\
\text { competence in matters relating to the use of } \\
\text { ionizing radiations }\end{array}$ & Annual concentration of $400 \mathrm{~Bq} / \mathrm{m}^{3}$ & $\begin{array}{l}\text { Where radon concentrations in home interiors } \\
\text { exceed } 400 \mathrm{~Bq} / \mathrm{m}^{3}, \text { engineering solutions must } \\
\text { be adopted for ventilating living spaces and } \\
\text { reducing emanations of the gas. }\end{array}$ \\
\hline Colombia (South America) & $\begin{array}{l}\text { Resolution 18-1434: Radiological Protection } \\
\text { and Safety Regulations }\end{array}$ & 2002 & Ministry of Mines and Energy & Mean annual concentration of $400 \mathrm{~Bq} / \mathrm{m}^{3}$ & - \\
\hline Guatemala (Central America) & $\begin{array}{l}\text { Government Resolution No. 55-2001: } \\
\text { Radiological Protection and Safety } \\
\text { Regulations pursuant to the Control, Use } \\
\text { and Application of Radioisotopes and } \\
\text { Ionizing Radiations Act }\end{array}$ & 2001 & $\begin{array}{l}\text { Ministry of Mines and Energy } \\
\text { President of the Republic }\end{array}$ & $\begin{array}{l}\text { Optimized action levels are, in general, in line } \\
\text { with the guidelines issued by the International } \\
\text { Atomic Energy Agency (IAEA), i.e., } 200-600 \\
\mathrm{~Bq} / \mathrm{m}^{3} \text { (assuming } 7000 \mathrm{~h} \text { per year in interiors } \\
\text { and an equilibrium factor of } 0.4 . \text { ) }\end{array}$ & $\begin{array}{l}\text { Management, taking into account the legal and } \\
\text { social circumstances applicable, must decide on } \\
\text { the compulsoriness of corrective actions for } \\
\text { situations of chronic exposure in homes. }\end{array}$ \\
\hline Nicaragua (Central America) & $\begin{array}{l}\text { Technical Directive No. 001-2011: technical } \\
\text { directive, technical regulations for protection } \\
\text { against ionizing radiations }\end{array}$ & 2011 & National Atomic Energy Commission & $\begin{array}{l}\text { It establishes radon limits according to the } \\
\text { International Atomic Energy Agency (IAEA) } \\
\text { Safety Series No. 115, namely: } 200-600 \mathrm{~Bq} / \mathrm{m}^{3} \\
\text { (assuming } 7000 \mathrm{~h} \text { per year in interiors and an } \\
\text { equilibrium factor of } 0.4 . \text {.) }\end{array}$ & $\begin{array}{l}\text { In situations of chronic exposure in homes, the } \\
\text { regulatory authority or intervening body must } \\
\text { decide whether the remedial actions are of a } \\
\text { mandatory nature or only in the form of a } \\
\text { recommendation, taking into account the } \\
\text { existing social and legal context. }\end{array}$ \\
\hline Paraguay (South America) & $\begin{array}{l}\text { National safety regulations for protection } \\
\text { against ionizing radiations and safety of } \\
\text { radiation sources }\end{array}$ & 2001 & $\begin{array}{l}\text { Ministry of Public Health and Social Welfare. } \\
\text { National Atomic Energy Commission }\end{array}$ & $\begin{array}{l}\text { It establishes radon limits according to the } \\
\text { International Atomic Energy Agency (IAEA) } \\
\text { Safety Series No. 115, namely: 200-600 Bq/ } \mathrm{m}^{3} \\
\text { (assuming 7000 h per year in interiors and an } \\
\text { equilibrium factor of } 0.4 . \text {.) }\end{array}$ & 0 \\
\hline Peru (South America) & $\begin{array}{l}\text { Supreme Decree No. 009-97-EM: } \\
\text { Radiological Safety Regulations }\end{array}$ & 1997 & $\begin{array}{l}\text { President of the Republic. Peruvian Institute } \\
\text { of Nuclear Energy }\end{array}$ & Mean annual concentration of 200 to $600 \mathrm{~Bq} / \mathrm{m}^{3}$ & - \\
\hline Uruguay (South America) & $\begin{array}{l}\text { Resolution 016/2014: Regulation UY 100, } \\
\text { basic Radiological Protection and Safety } \\
\text { Regulations. 8th Revision }\end{array}$ & 2018 & $\begin{array}{l}\text { National Radiological Protection Authority. } \\
\text { Ministry of Industry, Energy and Mining. }\end{array}$ & $\begin{array}{l}\text { It establishes radon limits according to the } \\
\text { International Commission on Radiological } \\
\text { Protection (ICRP) } 1993 \text { report No } 65 \text {, namely: } \\
200-600 \mathrm{~Bq} / \mathrm{m}^{3} \text { (assuming } 7000 \mathrm{~h} \text { per year in } \\
\text { interiors and an equilibrium factor of } 0.4 .)\end{array}$ & \\
\hline
\end{tabular}




\section{Discussion}

To our knowledge, this is the first systematic review to address the presence of residential radon in homes across Central and South America. It highlights the fact that very few measurements have been made in these countries and, very important, that the action level in all those countries which have set a statutory threshold is above $300 \mathrm{~Bq} / \mathrm{m}^{3}$, the maximum recommended by the World Health Organization (WHO) [47]. According to the studies reviewed, residential radon concentrations vary widely among the different countries and even within individual countries. These results also highlight the lack of legislation or statutory provisions targeted at preventing or blocking the seepage of radon into homes across Central and South America.

The studies reviewed report widely differing results on residential radon exposure. Thus, the high interior radon levels in the town of Lages Pintadas (Brazil) are linked to the fact that the town lies on a number of outcrops of pegmatite ore bodies, which are naturally enriched with uranium [33]. This agrees with what is already known about the way radon levels vary globally [48] according to bedrock characteristics [49]. It is noteworthy that the mean values recorded for Brazil are very close to those registered in Mexico, with $140 \mathrm{~Bq} / \mathrm{m}^{3}$ [47].

Our review located no data published on residential radon concentrations in any country in Central America, except Costa Rica. This is in line with the United Nations Scientific Committee on the Effects of Atomic Radiation (UNSCEAR) report (published in 2009), which provides evidence of residential radon action levels for countries on all continents, except Central America. It does however cite action levels for some South American countries, sourced from the studies by Canoba et al. (2002) and Zeeb (2007), with Canoba's being the most representative study to have been conducted in the region, owing to its inclusion of six countries and the number of measurements made $[45,50]$.

Brazil is the country in which most measurements have been made to assess exposure to residential radon. This may be due to the fact that from 1990 through 1994 it was the regional coordinating country for Latin America within the framework of the "Radon in the Human Environment" research program [51]. It should be borne in mind here that Brazil is the most populated and the largest country in Central and South America.

The greater use of the track detector method for measurement of residential radon can be explained by the fact that track detectors are passive devices requiring neither electric current nor a pump to function in the sampling environment, whereas active devices require electricity and enable continuous monitoring and recording of radon gas concentrations and fluctuations across the measurement period [47]. In addition, track detectors are cheaper than other types of detectors, and extremely reliable if used with the appropriate methodology [52] Many of the studies reviewed did not report the geometric mean or median, both of which are important measures, since radon concentrations tend to follow a log-normal distribution. Six studies were excluded after a reading of the full text because they measured radon in fewer than 10 homes. These studies were performed in countries already having indoor radon studies included in this review, and all of them had convenience sampling.

We did not find relevant differences between urban and rural settings. Though this can be seen as striking at first sight, some of the settings considered as urban included dwellings with low stories (i.e., ground floor and first floor), making them not very different to rural settings. Furthermore, some of the settings considered urban were located in areas with moderate radon concentrations exhaling from the soil, therefore somewhat high radon concentrations were expected.

Unlike countries in Europe, which have legislation governing recommended action levels, of the 16 countries that make up Central and South America, only seven have regulations that specifically indicate residential radon levels. Even so, in countries such as Guatemala, Nicaragua, Paraguay, Peru, and Uruguay, the maximum levels are up to $600 \mathrm{~Bq} / \mathrm{m} 3$, a figure equivalent to double that recommended in Europe [53], four times that recommended in the USA [54], and six times the ideal level suggested by the WHO [47].

The above results are not in line with the indications and recommendations issued by international institutions such as the ICRP, the European Atomic Energy Community (EURATOM), and UNSCEAR, 
to the effect that it falls to the state to issue regulations, take measurements, and make assessments in respect of ionizing and other radiation [50,55].

Apart from legislation stipulating residential radon action levels, it is also important to have laws governing home construction in order to protect people from radon, since high ${ }^{222} \mathrm{Rn}$ concentrations in homes can be reduced by means of corrective measures. These measures are aimed at preventing ${ }^{222} \mathrm{Rn}$ from seeping into homes/buildings from the soil, or eliminating it through better ventilation of interior spaces. No such legislation was, however, found for any of the Central and South American countries.

Notwithstanding the rigor of the search, the great diversity of websites from which the legislation-related documents were drawn (whether for sourcing recommended radon levels or building ordinances) makes it impossible to rule out the likelihood of regulations existing in any of the countries for which no statutory provisions were found. Moreover, it is always possible that such rules and regulations might be in the drafting phase.

It is important to highlight that the available evidence, besides scarce, is extremely heterogeneous in the number of radon measurements per study, methodology of measurement, and settings considered (rural, urban, radon-prone areas). This fact underlines the need to have nationwide studies allowing the robust description of indoor radon concentrations within a certain country. A further limitation is related to the period of measurement, with some studies having very short radon integration time compared to others, and a lack of full consideration of seasonal radon variations, a relevant issue in certain settings [56].

\section{Conclusions}

In general, it can be concluded that none of the countries analyzed has a global public health action targeted at tackling the problem of residential radon. The fact that only three studies have measured radon in more than 300 homes and the limited number of studies available means that in all of Central and South America there are very few initiatives of this type. As evidence of this, it should be noted that none of the countries in Central and South America has a national map of residential radon exposure or a unified legislative approach to combat the presence of radon in homes. There is also a very limited special coverage of residential indoor mapping, and WHO recommendations regarding indoor radon have not been enforced in any legislation of the analyzed countries. Part of the explanation for this may lie in the fact that, to date, these countries have had other health priorities, but now the time has come to address the problem of residential radon, given its association with lung cancer and the known interaction it displays with the smoking habit. It is vital that public administrations, health professionals, and the general public be made aware of the problem of residential radon, so that the necessary measures can be implemented to reduce its effects on health.

Author Contributions: A.R.-R., M.P.-R. and A.G.-O. were responsible for the conception and design; A.R.-R. and A.G.-O. were responsible for analysis, interpretation and drafting of the manuscript; and M.P.-R., L.V.-L. and J.M.B.-D. provided intellectual contributions, and reviewed and revised the manuscript. All authors have read and agreed to the published version of the manuscript. This paper forms part of the Ph.D. work conducting to the doctoral degree of Alexandra Giraldo-Osorio, scholarship holder of Fundación Carolina (C.2019).

Funding: This research received no external funding.

Acknowledgments: This paper forms part of the work leading to Alexandra Giraldo-Osorio's PhD degree.

Conflicts of Interest: The authors declare no conflict of interest.

\section{References}

1. Ruano-Raviña, A.; Quindós-Poncela, L.; Sainz Fernández, C.; Barros-Dios, J.M. Radón interior y salud pública en España. Tiempo para la acción. Gac. Sanit. 2014, 28, 439-441. [CrossRef] [PubMed]

2. World Health Organization. WHO Handbook on Indoor Radon: A Public Health Perspective; WHO Library Cataloguing-in-Publication Data: Geneva, Switzerland, 2009; ISBN 9789241547673. 
3. Ruano-Ravina, A.; Castro-Bernárdez, M.; Sande-Meijide, M.; Vargas, A.; Barros-Dios, J.M. Short- versus long-term radon detectors: A comparative study in Galicia, NW Spain. J. Environ. Radioact. 2008, 99, 1121-1126. [CrossRef]

4. Veloso, B.; Nogueira, J.R.; Cardoso, M.F. Lung cancer and indoor radon exposure in the north of Portugal—An ecological study. Cancer Epidemiol. 2012, 36, e26-e32. [CrossRef] [PubMed]

5. Vacquier, B.; Rogel, A.; Leuraud, K.; Caer, S.; Acker, A.; Laurier, D. Radon-associated lung cancer risk among French uranium miners: Modifying factors of the exposure-risk relationship. Radiat. Environ. Biophys. 2009, 48, 1-9. [CrossRef] [PubMed]

6. Turner, M.C.; Krewski, D.; Chen, Y.; Pope, C.A.; Gapstur, S.; Thun, M.J. Radon and lung cancer in the American Cancer Society Cohort. Cancer Epidemiol. Biomark. Prev. 2011, 20, 438-448. [CrossRef] [PubMed]

7. Krewski, D.; Lubin, J.H.; Zielinski, J.M.; Alavanja, M.; Catalan, V.S.; Field, R.W.; Klotz, J.B.; Létourneau, E.G.; Lynch, C.F.; Lyon, J.I.; et al. A combined analysis of North American case-control studies of residential radon and lung cancer. J. Toxicol. Environ. Health A 2006, 69, 533-597. [CrossRef]

8. Darby, S.; Hill, D.; Deo, H.; Auvinen, A.; Barros-Dios, J.M.; Baysson, H.; Bochicchio, F.; Falk, R.; Farchi, S.; Figueiras, A.; et al. Residential radon and lung cancer-Detailed results of a collaborative analysis of individual data on 7148 persons with lung cancer and 14,208 persons without lung cancer from 13 epidemiologic studies in Europe. Scand. J. Work Environ. Health 2006, 32, 1-84.

9. Darby, S.; Hill, D.; Auvinen, A.; Barros-Dios, J.M.; Baysson, H.; Bochicchio, F.; Deo, H.; Falk, R.; Forastiere, F.; Hakama, M.; et al. Radon in homes and risk of lung cancer: Collaborative analysis of individual data from 13 European case-control studies. BMJ 2005, 330, 223. [CrossRef]

10. International Agency for Research on Cancer; World Health Organization. IARC Monographs on the Identification of Carcinogenic Hazards to Humans. Available online: https://monographs.iarc.fr/agentsclassified-by-the-iarc/ (accessed on 25 November 2019).

11. Barbosa-Lorenzo, R.; Ruano-Ravina, A.; Cerdeira-Caramés, S.; Raíces-Aldrey, M.; Barros-Dios, J.M. Residential radon and lung cancer: A cohort study in Galicia, Spain. Cad. Saude Publica 2017, 33, e00189415. [CrossRef]

12. Lorenzo-González, M.; Ruano-Ravina, A.; Peón, J.; Pineiro, M.; Barros-Dios, J.M. Residential radon in Galicia: A cross-sectional study in a radon-prone area. J. Radiol. Prot. 2017, 37, 728-741. [CrossRef]

13. Piñeros, M.; Sierra, M.S.; Forman, D. Descriptive epidemiology of lung cancer and current status of tobacco control measures in Central and South America. Cancer Epidemiol. 2016, 44, S90-S99. [CrossRef] [PubMed]

14. International Agency for Research on Cancer; World Health Organization. Cancer Today: Estimated Number of Deaths in 2018, South America, Both Sexes, All Ages. Available online: https://gco.iarc.fr/today/online-analysis-table?v=2018\&mode=cancer\&mode_population=continents\& population $=900 \&$ populations $=931 \& \mathrm{key}=\mathrm{asr} \& \mathrm{sex}=0 \&$ cancer $=39 \&$ type $=1 \&$ statistic $=5 \&$ prevalence $=0 \&$ population_group $=0 \&$ ages_group $\% 5 \mathrm{~B} \% 5 \mathrm{D}=0$ \&ages_group $\% 5 \mathrm{~B} \% 5 \mathrm{D}=17 \&$ nb_items $=5 \&$ group $($ accessed on 28 November 2019).

15. Moher, D.; Liberati, A.; Tetzlaff, J.; Altman, D.G.; PRISMA Group. Preferred reporting items for systematic reviews and meta-analyses: The PRISMA statement. BMJ 2009, 339, 3-8. [CrossRef] [PubMed]

16. Urban, M.; Binns, D.A.C.; Estrada, J.J.; Karlsruhe, K.; Sicherheit, H. Radon Measurements in Mines and Dwellings. Available online: https://www.google.com.hk/url?sa=t\&rct=j\&q=\&esrc= s\&source=web\&cd=\&ved=2ahUKEwjvv8SciZfqAhUO7WEKHeWCDmEQFjAAegQIBxAB\&url= https\%3A\%2F\%2Fpublikationen.bibliothek.kit.edu\%2F270021042\%2F3812851\&usg=AOvVaw2aW6COwlzeVj2JnVnFDmm (accessed on 15 May 2020).

17. Loría, L.G.; Jiménez-Dam, R.; Gallardo, M. Estudio preliminar de la contaminación por gas radón en recintos habitacionales en Costa Rica. Rev. Tecnol. Marcha 1993, 12, 19-27.

18. Gomez, J.C.; Oliveira, A.A.; Arnaud, M.I.; Ciallella, H.B. Radon in dwellings in Argentina. In Proceedings of the International conference on high levels of natural radiation, Ramsar, Iran, 3-7 November 1990; International Atomic Energy Agency: Ramsar, Iran, 1990; pp. 391-397.

19. Canoba, A.C.; Arnaud, M.I.; López, F.O.; Oliveira, A.A. Mediciones de gas radón en el interior de viviendas de la República Argentina. In Proceedings of the 4 Congreso Regional en Seguridad Radiológica y Nuclear, La Habana, Cuba, 19-23 October 1998; Autoridad Regulatoria Nuclear: La Habana, Cuba, 1998; pp. 1-6.

20. United Nations Scientific Committee on the Effects of Atomic Radiation. UNSCEAR 2000 Report-Vol. I: Sources and Effects of Ionizing Radiation Annex B Exposures from Natural Radiation Sources; UNSCEAR: New York, NY, USA, 2000; ISBN 92-1-142238-8. 
21. Canoba, A.; López, F.O.; Arnaud, M.I.; Oliveira, A.A.; Neman, R.S.; Hadler, J.C.; Iunes, P.J.; Paulo, S.R.; Osorio, A.M.; Aparecido, R.; et al. Indoor radon measurements and methodologies in Latin American countries. Radiat. Meas. 2001, 34, 483-486. [CrossRef]

22. Canoba, A.C.; López, O.F. Mediciones de radón 222 en el interior de viviendas de la República Argentina. In Proceedings of the Primer Congreso Americano del International Radiation Protection Association (IRPA), Acapulco, México, 4-8 September 2006; International Radiation Protection Association (IRPA): Acapulco, Mexico, 2006; p. 10.

23. Zeeb, H. International Radon Project: Survey on Radon Guidelines Programmes and Activities; Final Report; WHO/HSE/RA; World Health Organization: Geneva, Switzerland, 2007.

24. De Paula Melo, V. Avaliação da Concentração do 222Rn nos Ambientes Internos e Externos em Residências do Município de Monte Alegre, PA; Universidade Federal do Rio de Janeiro: Rio de Janeiro, Brazil, 1999.

25. Guedes, S.; Hadler, N.; Iunes, P.J.; Navia, L.; Neman, R.; Paulo, S.; Rodrigues, V.; Souza, W.; Tello, C.; Zúñiga, A. Indoor radon and radon daughters survey at Campinas-Brazil using CR-39: First results. Radiat. Meas. 1999, 31, 287-290. [CrossRef]

26. Veiga, L.H.S.; Koifman, S.; Melo, V.P.; Sachet, I.; Amaral, E.C.S. Preliminary indoor radon risk assessment at the Poços de Caldas Plateau, MG-Brazil. J. Environ. Radioact. 2003, 70, 161-176. [CrossRef]

27. Magalhães, M.H.; Amaral, E.C.S.; Sachett, I.; Rochedo, E.R.R. Radon-222 in Brazil: An outline of indoor and outdoor measurements. J. Environ. Radioact. 2003, 67, 131-143. [CrossRef]

28. Paulo, S.R.; Neman, R.; Hadler Neto, J.C.; Iunes, P.J.; Guedes, S.; Balan, A.M.O.A.; Tello, C.A.S. Radon surveys in Brazil using CR-39. Radiat. Meas. 2005, 39, 657-660. [CrossRef]

29. De Olveira Santos, T.; Rocha, Z. Indoor radon measuarements in dwellings and other buildings in the metropolitan region of Belo Horizonte, Brazil. In Proceedings of the International Nuclear Atlantic Conference-INAC; Associação Brasileira de Energia Nuclear-ABEN: Santos, SP, Brazil, 2007; Available online: https://www.ipen.br/biblioteca/cd/inac/2007/pdf_dvd/E04_1778.pdf (accessed on 25 November 2019).

30. Hadler, J.; Neman, R.; Iunes, P.; Pereira, O.; Paulo, S. Indoor radon and radon progeny survey at Campinas-Brazil using CR-39: Final results. Radiat. Meas. 2008, 43, S440-S444. [CrossRef]

31. Santos, T.O.; Rocha, Z.; Barreto, A.A.; De Souza, L.A.C.; Miguel, R.A.; De Oliveira, A.H. Indoor Radon Distribution in Metropolitan Region of Belo Horizonte, Brasil; Associação Brasileira de Energia Nuclear-ABEN: Rio de Janeiro, Brazil, 2009; ISBN 978-85-99141-03-8. Available online: https://inis.iaea.org/collection/ NCLCollectionStore/_Public/41/109/41109064.pdf (accessed on 25 November 2019).

32. Campos, T.; Petta, R.; Pastura, V. Residential radon and the risk of malignity: The case of lages pintadas city, northeastern Brazil. In Proceedings of the 4th International Conference on Medical Geology, Bari, Italy, 20-25 September 2011.

33. Campos, T.; Petta, R.; Malanca, A.; Pastura, V.; Sichel, S.; Motoki, A. O Gás Radônio E a Radiação Natural Em Terrenos Metagraníticos E Pegma-Títicos: O Caso Do Município De Lages Pintadas (Rio Grande Do Norte, Brasil). Geologia 2013, 26, 45-52.

34. Malanca, A.; De Azevedo, L.L.; Repetti, M.; Gaidolfi, L. Background airborne radioactivity in an equatorial Brazilian town. J. Radioanal. Nucl. Chem. 1997, 221, 189-191. [CrossRef]

35. Malanca, A.; Gaidolfi, L. Environmental Radon in Some Brazilian Towns and Mines. Radiat. Prot. Dosim. 1997, 69, 211-216. [CrossRef]

36. Stuardo, E. Natural Radiation Measurements in Chile. Radiat. Prot. Dosim. 1996, 67, 129-133. [CrossRef]

37. Salazar, S. Mapa Geoquímico del gas Radón para Suroriente del Municipio de Manizales, Grado; Universidad de Caldas: Caldas, Colombia, 2002.

38. Loayza Cabrera, M.J. Elaboración de un Mapa Radiológico de los Niveles de Radon Presentes en las Viviendas de las Parroquias Urbanas de la Ciudad de Cuenca-Ecuador en el Periodo 2017-2018, Grado; Universidad Politécnica Salesiana: Cuenca, Ecuador, 2018.

39. Carrasco, J.; Cudrado, C. Medición de la concentración de 222 Rn en residencias y lugares de trabajo en la ciudad de Riobamba. In Proceedings of the XVI International Symposium on Solid State Dosimetry, Chiapas, México, 24-28 September 2016; pp. 1-14.

40. Pereyra, P.; López, M.E.; Vilcapoma, L. Concentration Measurements of Radon 222 Indoors in Lima-Peru. Int. J. Phys. 2015, 3, 165-169. [CrossRef] 
41. Pereyra, P.E.; López, M.E.; Vilcapoma, P.L.; Pérez, B.A.; Rojas, J.J. Mediciones de la concentración de radón 222 en residencias de Lima y Callao-Perú. In Proceedings of the X Congreso Regional Latinoamericano IRPA de Protección y Seguridad Radiológica: Radioprotección: Nuevos Desafíos para un Mundo en Evolución; Sociedad Argentina de Radioprotección: Buenos Aires, Argentina, 2015; p. 11. Available online: https://www. irpabuenosaires2015.org/Archivos/tr-completos/irpa/1_Pereyra_IRPA_2015_Primertrabajo.pdf (accessed on 25 November 2019).

42. Liza Neciosup, R.A. Mapeo de los Niveles de Radón 222 en el Distrito de San Martín de Porres (Lima-Perú) en el Periodo 2015-2016, Grado; Pontificia Universidad Católica del Perú: Lima, Peru, 2017.

43. Vega Cabrera, B.O. Monitoreo de la Concentración de la Actividad de Rn-222 en el Distrito de San Luis-Lima Durante los Años 2015-2016; Pontificia Universidad Católica del Perú: Lima, Peru, 2017.

44. Sajó-Bohus, L.; Pálfalvi, J.; Urbani, F.; Castro, D.; Greaves, E.D.; Liendo, J.A. Environmental gamma and radon dosimetry in Venezuela. Radiat. Meas. 1999, 31, 283-286. [CrossRef]

45. Canoba, A.; López, F.O.; Arnaud, M.I.; Oliveira, A.A.; Neman, R.S.; Hadler, J.C.; Iunes, P.J.; Paulo, S.R.; Osorio, A.M.; Aparecido, R.; et al. Indoor radon measurements in six Latin American countries. Geofísica Int. 2002, 41, 453-457.

46. Da Costa Dantas, R.; Navoni, J.A.; Souza de Alencar, F.L.; Da Costa Xavier, L.A.; Souza do Amaral, V. Natural radioactivity in Brazil: A systematic review. Environ. Sci. Pollut. Res. 2020, 27, 143-157. [CrossRef]

47. Organzación Mundial de la Salud. Manual de la OMS Sobre el Radón en Interiores: Una perspectiva de salud Pública; Organización Mundial de la Salud: Geneva, Switzerland, 2015; ISBN 9789243547671.

48. Ruano-Ravina, A.; Wakeford, R. The Increasing Exposure of the Global Population to Ionizing Radiation. Epidemiology 2020, 31, 155-159. [CrossRef] [PubMed]

49. Ruano-Ravina, A.; Kelsey, K.T.; Fernández-Villar, A.; Barros-Dios, J.M. Action levels for indoor radon: Different risks for the same lung carcinogen? Eur. Respir. J. 2017, 50, 1-4. [CrossRef] [PubMed]

50. United Nations Scientific Committee on the Effects of Atomic Radiation Effects of Ionizing Radiation. Annex E-Sources-to-Effects Assessment for Radon in Homes and Workplaces; UNSCEAR 2006 Report; UNSCEAR: New York, NY, USA, 2009; Volume II, pp. 1-142.

51. Binns, D.A.C.; Figueiredo, N.; Melo, V.P.; Gouvea, V.A. Radon-222 measurements in a uranium-prospecting area in Brazil. J. Environ. Radioact. 1998, 38, 249-254. [CrossRef]

52. Rabago, D.; Fuente, I.; Celaya, S.; Fernandez, A.; Fernandez, E.; Quindos, J.; Pol, R.; Cinelli, G.; Quindos, L.; Sainz, C. Intercomparison of indoor radon measurements under field conditions in the framework of metroradon european project. Int. J. Environ. Res Public Health 2020, 17, 1780. [CrossRef] [PubMed]

53. Council Directive Council Directive 2013/59/Euratom. Off. J. Eur. Union 2014, 17, 73. [CrossRef]

54. United State Environmental Protection Agency. Radon Reference Manual; EPA: Washington, DC, USA, 1987.

55. Espinosa-García, G.C.; Ángeles-Carranza, A. Radon Intramuros y Salud Pública; Primera.; Universidad Nacional Autónoma de México: Ciudad de México, Mexico, 2018; ISBN 978-607-05-8917-9.

56. Park, J.H.; Lee, C.M.; Lee, H.Y.; Kang, D.R. Estimation of seasonal correction factors for indoor radon concentrations in Korea. Int. J. Environ. Res. Public Health 2018, 15, 2251. [CrossRef] [PubMed]

(C) 2020 by the authors. Licensee MDPI, Basel, Switzerland. This article is an open access article distributed under the terms and conditions of the Creative Commons Attribution (CC BY) license (http://creativecommons.org/licenses/by/4.0/). 